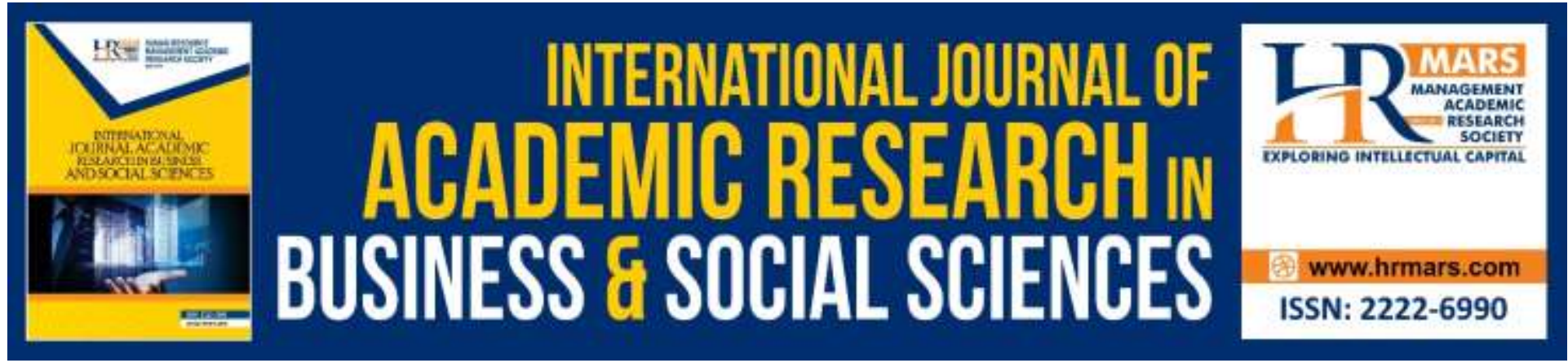

\title{
Financial Cooperatives based on Waqf for Affordable Housing in Karachi
}

\begin{abstract}
Muhammad Kashif Khan, Siti Zaleha Abd Rasid, Barjoyai Bin Bardai, Batool Fatima
\end{abstract}

To Link this Article: http://dx.doi.org/10.6007/IJARBSS/v9-i8/6223

DOI: $10.6007 /$ IJARBSS/v9-i8/6223

Received: 02 May 2019, Revised: 17 June 2019, Accepted: 30 July 2019

Published Online: 03 August 2019

In-Text Citation: (Khan, Rasid, Bardai, \& Fatima, 2019)

To Cite this Article: Khan, M. K., Rasid, S. Z. A., Bardai, B. bin, \& Fatima, B. (2019). Financial Cooperatives based on waqf for affordable housing in Karachi. International Journal of Academic Research in Business and Social Sciences, 9(8), 134-143.

Copyright: (C) 2019 The Author(s)

Published by Human Resource Management Academic Research Society (www.hrmars.com)

This article is published under the Creative Commons Attribution (CC BY 4.0) license. Anyone may reproduce, distribute, translate and create derivative works of this article (for both commercial and non-commercial purposes), subject to full attribution to the original publication and authors. The full terms of this license may be seen

at: http://creativecommons.org/licences/by/4.0/legalcode

$$
\text { Vol. 9, No. 8, 2019, Pg. } 134 \text { - } 143
$$

Full Terms \& Conditions of access and use can be found at http://hrmars.com/index.php/pages/detail/publication-ethics 


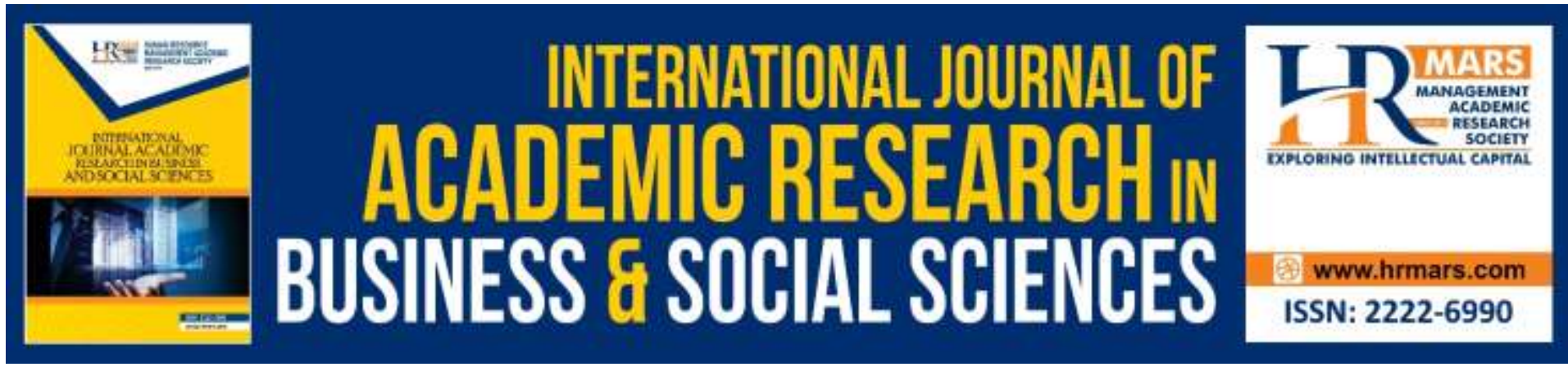

\title{
Financial Cooperatives based on Waqf for Affordable Housing in Karachi
}

\author{
Muhammad Kashif Khan ${ }^{1}$, Siti Zaleha Abd Rasid², Barjoyai Bin \\ Bardai $^{3}$, Batool Fatima ${ }^{4}$ \\ 1,2,3 Azman Hashim International Business School, Universiti Teknologi Malaysia, Kuala \\ Lumpur, Malaysia, ${ }^{4}$ Compliance Department, First Women Bank Limited, Karachi, Pakistan \\ Email: kkmuhammad2@live.utm.my
}

\begin{abstract}
The issue of affordable housing in Karachi has been a concern as two third of Karachi population is considered poor. These low incomes earning people of Karachi have been striving hard for shelter for a long time but unable to do so because of their low disposable income. They have been caught in a dilemma between spending on high rentals or on other necessities such as education, nutrition etc. since many decades. As a result, they are forced to live in illegal settlements or slums where they are compelled to compromise on their social/ethical values and better upbringing of their children. It is estimated that around eighty thousand homes are required each year in Karachi and because of constantly increasing fiscal and budgetary deficits, Pakistan government is unable to cater to this demand. The purpose of this study is to offer a solution to fill up this wide gap between demand and supply situation of housing units in Karachi through creating a synergy between housing cooperative and waqf. Moreover, this paper attempts to identify two innovative waqf based financing tools to overcome the problem of lack of initial funding for the development of housing cooperatives. Keywords: Affordable Housing, Cooperative Housing, Waqf, Cash Waqf, Sukuk.
\end{abstract}

\section{Introduction}

Shelter is, primarily, a basic human need. With it, humans will be able to protect themselves against hostile surroundings. Consequently, they are more likely to lead fulfilling, productive and happier lives (Nafar, 2018). Housing is something that is beyond physical dimension.

The vast social, political and economic spillover effects by having the roof ownership over one's head cannot be denied. A house is an investment asset whose value generally grows over time and therefore coupled as means of wealth accumulation and savings (Baqutaya, Ariffin, \& Raji, 2016; Cityu, Paper, \& No, 2014; Nafar, 2018). Thus, as a long-term asset, the ownership of home helps to contribute to prosperity, peace and stability of a nation.

A large part of Karachi's population requires access to additional funds to own a house (Hamid \& Masood, 2011; A. Hasan, 2015). To that end, a focal point of a successful home ownership program in any given nation is access to home financing (Aini, Aziz, \& Hanif, 2015; Nafar, 
2018). In general, there are two types of home financing in Pakistan, i.e., conventional and Islamic. The majority chunk of home loans accounted to conventional mode of home financing where the loan is repaid over an agreed upon tenure along with interest by the borrower (Hamid \& Masood, 2011; Planning, 1992). In conventional mode, banks usually charge either a variable or fixed interest rate (or a combination of the two).

So far, two financing modes have been used to finance cooperatives for affordable housing which are incompatible with the aims of pro poor housing as it is an accepted fact that the poor cannot meet the stringent loan requirements and documentation of bank debt (Muhammad, 2016; Jha 2006). Moreover excessive use of bank debt results in increasing inflation at macro level (Jha, 2006). Another avenue to finance housing development for shelter less poor people is through public finance. However, because of the increasing fiscal deficits, this option is also not feasible at a constant basis (Zabri et. al, 2016). Therefore, there is a need to introduce innovative financing tools for cooperative affordable housing that not only serves the purpose of provision of affordable housing to poor without placing any burden on the public exchequer. The issue of lack of affordable housing in Karachi and the accompanying problem of financing of any housing cooperative to resolve the issue of affordable housing is discussed in this study. Two innovative waqf based Islamic financing tools that are cash waqf and waqf sukuk have been identified. Both waqf based financing tools are mutually exclusive and thus may be used in combination. Therefore, the objective of this study is "to introduce innovative waqf based financing tools for housing cooperatives to resolve the problem of affordable housing in Karachi."

The rest of this paper is structured as follows. The following section discusses the relevant literature for understanding of affordable housing issue in Karachi, debt based financing and public sector financing to cooperatives, conclusions, limitations and subsequent research directions related to the study of this proposed topic.

\section{Literature Review}

This study involves review of extant literature related to the problem of lack of affordable housing specifically in the largest city of Pakistan, Karachi. Moreover, a review of an initiative based of cooperatives as well as traditional tools for home financing has been undertaken. Finally, two innovative waqf based financing tools to overcome the problem of initial funding for cooperatives were identified.

\section{Karachi: A Mega Metropolitan City}

The Federation of Pakistan is consisted of four provinces and its south eastern province is Sindh whose capital is Karachi. Being the largest city of Pakistan; Karachi is the fastest growing megacity if we take into account the annual increase in its population according to a house count census conducted in the year 2013 (Hasan, 2015). Out of the total population of Pakistan, 9\% live in Karachi and out of the total urban population of Pakistan, 25\% live in this megacity. When we talk about resources, Karachi's share is $25 \%$ in overall revenues of Pakistan, $62 \%$ in income tax and 15\% GDP out of the total for the whole country (Nausheen \& Anwar, 2014; Hasan, 2015).

According to several estimates, the demand for housing in Karachi is 80,000 new housing units 
every year (Nausheen \& Anwar, 2014; Hasan, 2015; Qureshi, Breuste, \& Lindley, 2010). In this regard, approximately 32,000 houses are supplied by the formal sector while approximately 30,000 units are provided by the informal sector that are called katchi abadis (illegal settlements). There is an incessant expansion of these katchi abadis as around $75 \%$ of Karachi population is classified as poor who become the majority of the unencountered demand for housing units (Hasan, 2015; Planning, 1992; Ravallion, Chen, \& Sangraula, 2007).

Out of the total residential area that is $36 \%$ of the total area, $74 \%$ is built formally for a population of $38 \%$ while the remaining $26 \%$ area cater to $62 \%$ population that lives in Karachi (Nausheen \& Anwar, 2014; Hasan, 2015; Hasan, 2010; Qureshi et al., 2010). This indicate injustice and inequity towards the poor that leads to ethnic and class conflict. In order to overcome this difficulty, government of Pakistan has taken several initiatives such as the transformation of House Building Finance Corporation (HBFC) that aimed at providing loans and initiation of a new institution Katchi Abadi Improvement and Regularisation Programme (KAIRP) that aimed at building apartments and regularization of illegal settlements (Nausheen \& Anwar, 2014; Haider \& Badami, 2010; Hasan, 2015).

Despite changes in housing finance processes and packages by the government, the loans do not reach at the door step of poor because of non-availabiility of suitable required jobs necessary to avail these loans ( $3 / 4^{\text {th }}$ of Karachi population work in informal sector), nonavailability of collateral and high rates of interest. Moreover, the corruption of public officials put the last nail in the coffin as these poor people are required in some cases to pay large sums as bribes or speed money (Ahmed, 2008; Nausheen \& Anwar, 2014; Hasan, 2015; Qureshi et al., 2010).

Because of the poor law and order conditions, absence of the writ of government, frauds by private house developers, flagrant corruption etc; poor and middle class Karachiites who wish to purchase, sell or rent their accommodation feel helpless. They do not know that any housing project in which they want to invest with a dream to own housing unit for themselves is legal. They choose to live in neighborhoods where people belong to their own religion/ethnicity and they prefer to rent their property to person belong to their own religion and ethnicity. This trend is horrible as it is dividing the city into ethnic and religious lines (Hasan, 2015).

Poor Karachiites who can only afford to live in the peripheral areas of the city face some serious problems in the form of wasted time, extra costs of transportation and discomfort. Improper schooling for children, leaving home early and getting late in reaching home at night by the fathers and impossibility of working for women who has the prime responsibility to look after their families are some of the consequences living at the periphery (Ahmed, 2008; Hasan, 2015; Planning, 1992; Qureshi et al., 2010). It is therefore feasible for them to relocate to inner city which is cheaper and convenient. However, such relocation leads to densification of city's informal settlements (Nausheen \& Anwar, 2014; Hasan, 2015).

Several case studies regarding the settlements demonstrated that the densities of persons residing in inner area of Karachi city has been increased from 600 to 4000 individuals per hectare (Ahmed, 2008; Qureshi et al., 2010). This consequently created a lot of social and 
physical issues as more than 10 individuals staying in a single room, newly wed couples without a private space, children start taking drugs and form gangs, shared toilets and kitchens that leads to conflicts etc (Nausheen \& Anwar, 2014; Hasan, 2015).

Because of a wide gap between a meagre supply of housing units and increasing demand (because of increasing population and urbanization); the land price increased significantly in the past few years in Karachi thereby forced the middle class and poor to acquire shelter on rent which put pressure on the available places thereby increase the rentals for their disadvantaged tenants who are the most vulnerable group in housing (Ahmed, 2008; Nausheen \& Anwar, 2014; Hasan, 2015; Hatem A. El-Karanshawy et.al, 2015; Qureshi et al., 2010). Several researches are evident that such tenants live in extremely overcrowded conditions with six to eight individuals in a room (Nausheen \& Anwar, 2014; Cheema, Khwaji, \& Qadir, 2006; Haider \& Badami, 2010; Hasan, 2015; Shuid, 2011). Moreover, they cannot feed their families properly because of high rents and transportation costs and consequently they are not left with any savings. All of this points to a gruesome fact, that because of their high expenses there is no opportunity for them to own a house throughout their lives.

Islamic home financing products as one of the largest asset category in the portfolio of commercial banking industry of Pakistan, is gaining momentum at $27.2 \%$ per annum and outpaced the $10.7 \%$ average growth of conventional home finance in a short period of three years (2011-2014). Islamic home loans in Pakistan are typically based on the bay' bithaman ajil (BBA) and more recently, diminishing musharakah partnership arrangement. The concept of buy and sell is involved in the whole transaction of BBA where the house is procured by the Islamic commercial bank first and then a sale arrangement is made with the customer at an agreed price. The selling price includes the house cost and profit (markup) that is also based upon a variable or fixed profit rate according to market. Whereas, in diminishing musharakah, a partnership (which is similar to leasing arrangement) is formed between the bank and the customer in which the bank rent out its share to the customer.

As a Muslim-majority nation, the elements of Shari'ah and its underlying business ethics continue to play an integral part of affective commitment dimension as it was outlined in most of Islamic home financing's selection criteria literature. Specifically, among others, it includes emphasis on Shari'ah principles in the Islamic home financing products and services, unambiguity and transparency in the transactions, thereby preventing riba.

\section{Debt Based and Equity based Islamic Home Finance}

The debt based Islamic home finance has been under severe criticism from professionals and scholars because of its similarity to conventional finance (Abozaid, 2016; Amin, Rahman, \& Razak, 2014; Shafii \& Rahman, 2016; Zabri, Mohammed, \& Mohammed, 2018). Currently, Islamic debt based home finance rely heavily on Mudarabah and therefore a mark up is added over it which most of the time is comparatively more costlier than conventional interest based home finance. Any incremental movement of mark up rates negatively affects the disposable income of the client which in turn make this debt based arrangement unaffordable (Amin et al., 2014; Hamid \& Masood, 2011; Zabri et al., 2018). Therefore, it has been suggested that an equity based Islamic home financing arrangement should be used to avoid the shortcomings of debt based home finance. However, equity based financing based on 
Musharakah or Istisna' also faced the issue of mark up rate rise because like every bank product, market based mark up is inherent in equity based financing as well therefore both debt based and equity based bank financing are unable to resolve the issue of financing of affordable housing so far (Amin et al., 2014; Hamid \& Masood, 2011; Shafii \& Rahman, 2016; Zabri et al., 2018).

\section{Public Sector Home Financing}

Not a single home financing scheme in the history can become successful without the active support of government. It is the responsibility of government, being the most powerful stakeholder to play a supporting role in the development of housing finance systems (Biygautane, Neesham, \& Al-yahya, 2019; Ismail \& Shaikh, 2016). The underserved shelter less segment of population is present alike in both developed as well as undeveloped societies and it is the responsibility of every government as a welfare state to provide shelter to this segment as it is considered as a basic necessity of survival (Biygautane et al., 2019; Nafar, 2018). However, with the increasing fiscal deficits, increasing financial obligations and a wide gap between housing demand and supply it is not practically feasible for a government to provide shelter to this large chunk of population out of public exchequer (Authors, 2018; Zabri et al., 2018).

Therefore, financial cooperatives appear to be an ideal alternative for affordable home financing where the finances are provided by the members themselves for their own benefit.

\section{Financial Cooperatives as an Affordable Islamic Home-Financing Provider}

Cooperative mode of home financing operates when a certain group of people get together to raise funds among themselves for a specific purpose i.e., purchasing a house for its members (Smolo \& Hassan, 2011; Zabri et al., 2018). The funds serve as a specialised mutual savings for members of the cooperative. In this situation, Smolo \& Hassan (2011) explains, "unlike formal mortgage, the member whom the house is being purchased shall pay the principal along with an additional amount to the cooperative. Such amount is paid in lieu of an interest payment in formal mortgage. This simultaneous action will, therefore, enable the member to offset the cost of borrowing with the benefit of lending, thus resulting to a facility with zero interest payment".

Some of the prime examples of cooperative home financing based on MMP concept are American Finance House LARIBA (AFHL) in the USA and Ansar \& Islamic Cooperative Housing Corporation Ltd. in Canada. According to this model, a financial cooperative and the membercustomer would purchase the house together. The financial cooperative agrees to sell its shares to the member-customer, while the member-customer agrees to repurchase these shares. In this regard, the financial cooperative allows the member-customer to buy the house directly from the developer and register it under his/her name (Authors, 2018; Smolo \& Hassan, 2011; Zabri et al., 2018). The member-customer leases the financial cooperative's shares in the house and gradually repurchases its shares. The house is leased at market value, which is defined by the location and specification of the house and mutually agreed between the financial cooperative and member-customer. This rent value is proportionately divided between two of them in accordance of their shares of the purchase price of the house. The additional amount is paid by the member-customer as instalment for buying back the shares 
of financial cooperative. Gradually, the member-customer's shares in the property increases while the financial cooperative's shares diminish with each instalment, until the end of the financing period when the member-customer will own 100 per cent of the shares in the property (Authors, 2018; Maali \& Atmeh, 2015; Mohsin, 2013; Smolo \& Hassan, 2011; Zabri et al., 2018).

\section{Lack of Initial Financing for Cooperatives: A Potential Role of Waqf Based Innovative Financing Tools}

Generally, there is a lack of complimentary funding in almost all arrangements based on cooperatives because of their dependency on member deposits, capital shares etc. which in most of the cases are not sufficient to achieve the end of development of shelter for its members (Institutions \& Mohammed, 2016; Zabri et al., 2018). Traditionally, these cooperatives are left with only one avenue for initial financing and that is bank loan to finance development cooperative. When these cooperatives use bank financing they fall into trouble as they are obligated to pay higher returns which are not affordable most of the time and thus the cooperative compromise on its original aim that is to resolve the issue of affordable housing to its members (Institutions \& Mohammed, 2016; Suzuki \& Miah, 2016; Zabri et al., 2018). Thus, there is a need to introduce other innovative avenues for financing cooperative development. Islamic finance has gained momentum in recent times as its has the potential to offer innovative solutions to problems such as the lack of complementary financing for cooperatives. Islamic finance tools based on waqf such as cash waqf and waqf sukuk may enable the cooperative to resolve the problem of initial financing for its development.

\section{Role of Waqf Sukuk and Cash Waqf in Cooperative Financing Cash Waqf}

Cash waqf is a process of lending cash to those who are entitled and does not have enough resources to cater to their basic needs without any interest. According to Hanafi school of thought, "Cash waqf is the process of dedicating cash as waqf and investment of same so that the profits are used for the waqf's stipulated charitable deeds" (Ahmad, 2015; p.65). Cizakca (2013) defined cash waqf as establishing a charitable endowment through cash.

The donor for this cash waqf may be individuals, governments, corporations and institutions. This fund through cash waqf will follow Waqf Aam that is charitable waqf because this could not fall under the purview of Waqf Ahli (Private or family waqf). Moreover, waqf interest would be waqf mutlaq for this study and not waqf muqayyad, as the donor will delegate its authority to manage the waqf fund to waqf management authority that is termed as nazir (administrator) or mutawwali. Islamic commercial bank will act as nazir in this arrangement.

\section{Waqf Sukuk}

Waqf Sukuk works as traditional Sukuk however the only difference is that the asset that is used for issuance of Sukuk is waqf asset (Ismal, 2015). Awqaf New Zealand recently issued Waqf Sukuk certificates and the modus operandi of these Awqaf Sukuks is as follows (Cizakca, 2016):

1- The asset that is used for Sukuk issuance is a farm that is a waqf asset.

2- These Sukuk certificates are offered to global investors. 
3- These certificates are 'not for profit' and the profit, if any generated, will be given to charity.

4- The government of New Zealand guarantee the redemption and payment of these certificates.

5- Sukuk will be redeemed and investors will be paid back their money at a future fixed date.

Thus, waqf based sukuk as an innovative Islamic financial tool may provide the necessary impetus to carry out welfare endeavors by the government or by corporate. These waqf sukuk may provide the necessary inter linkage between public sector, financial sector and social sector to achieve the Maqasid e Shariah.

In our study, retail sukuk will be offered for subscription to retail investors that belong to mostly general public. This low-income group will then subscribe to the cooperative as a member and pay a nominal rental amount perpetually and these rentals will also be reinvested as a part of cooperative pool so that it can finance further projects with the same aim to provide affordable low cost housing for low income group. This cooperative will be managed by a professional management body which may be a Islamic financial institutions such as any Islamic commercial bank. A mechanism keeping in view a recent example from Malaysia may be followed in which perpetual sukuk by Malaysian airlines were issued and the transaction was advised by Maybank. These perpetual sukuk were issued without any maturity date without any fixed annuities and hence repayment of principal was not obligatory by MAS (Cizakca, 2016).

\section{Research Limitations}

It may be understandably assumed from above discussion that because cooperatives, waqf, cash waqf and waqf sukuk are innovative concepts of Islamic finance therefore their understanding is limited. It is evident from previous section that because WCHM is an innovative mechanism therefore its understanding is so far limited. Although utmost care has been taken in this paper to cover all the aspects of the problem of affordable housing and financing of any cooperative based initiative, it is understandably assumed that this review is not exhaustive. The reasons behind this assumption are, this review has been undertaken according to Karachi and Pakistan and therefore its generalizability is limited.

\section{Conclusion}

It can be seen from the discussion that waqf based cooperative arrangement is an innovative and practical solution to the problem of affordable housing. Any such arrangement has the potential to not only provide affordable housing to poor people but also support the government to discharge one of its prime responsibility that is to provide shelter to shelter less population without burdening the national exchequer.

The appropriate future research questions would be: how cost benefit analysis may be done of any waqf based cooperative arrangement? what problems may arise with the practical implementation of such arrangement? what are the facilitating and hindering factors for this arrangement? As this is an innovative arrangement therefore there is a need to determine that how awareness regarding this waqf based cooperative arrangement may spread. Finally, 
there is a need to find out if any such arrangement is successful in Karachi in particular and in different cultural contexts in general so that it may be introduced at a wider scale. Any such future study could be qualitative, quantitative, or use a mixed method approach.

\section{References}

Abozaid, A. (2016). The Internal Challenges Facing Islamic Finance Industry. International Journal of Islamic and Middle Eastern Finance Management, 9(2), 1-20. https://doi.org/10.1108/IMEFM-05-2015-0056

Ahmad, M. (2015). Cash Waqf : Historical Evolution, Nature and Role as an Alternative to Riba -Based Financing for the Grass Root. Journal of Islamic Finance, 4(1), 63-74.

Ahmed, N. (2008). Karachi in 2020: approaching planning as a project. Proceedings of the ICE - Urban Design and Planning, 161(3), 123-129. https://doi.org/10.1680/udap.2008.161.3.123

Aini, A. M., Aziz, W. N. A. W. A., \& Hanif, N. R. (2015). To move or not to move?: exploring future housing plan of ageing communities in Kuala Lumpur. The Asia Pacific Network for Housing Research (APNHR) Conference, Gwanju, Korea, (APRIL).

Amin, H., Rahman, R. A., \& Razak, A. D. (2014). Consumer acceptance of Islamic home financing. International Journal of Housing Markets and Analysis, 7(3), 307-332. https://doi.org/10.1108/IJHMA-12-2012-0063

Author, L., \& Anwar, N. H. (2014). Violence in Millennial Karachi : A Scoping Study, (February).

Authors, F. (2018). Examining the behavioral intention to participate in a Cash Waqf Financial Cooperative- Musharakah Mutanaqisah home financing model. https://doi.org/10.1108/MF-05-2017-0189

Baqutaya, S., Ariffin, A. S., \& Raji, F. (2016). Affordable Housing Policy: Issues and Challenges among Middle-Income Groups. International Journal of Social Science and Humanity, 6(6), 433-436. https://doi.org/10.7763/IJSSH.2016.V6.686

Biygautane, M., Neesham, C., \& Al-yahya, K. O. (2019). ScienceDirect Institutional entrepreneurship and infrastructure public-private partnership ( PPP ): Unpacking the role of social actors in implementing PPP projects. International Journal of Project Management, 37(1), 192-219. https://doi.org/10.1016/j.ijproman.2018.12.005

Cheema, A., Khwaji, A., \& Qadir, A. (2006). Local Government Reforms In Pakistan: Context, Content And Causes. Decentralization and Local Governance in Developing Countries, (April), 257-284. https://doi.org/10.1017/CBO9781107415324.004

Cityu, G., Paper, W., \& No, W. P. (2014). Recent trends on housing affordability research : where are we up to ? Jing LI City University of Hong Kong, (5).

Conference, G. W. (2016). MURAT ÇIZAKÇA MERGING WAQF AND SUKUK : SHOULD WE OR SHOULDN' T WE ?, (September).

Haider, M., \& Badami, M. G. (2010). Urbanization and Local Governance Challenges in Pakistan. Environment and Urbanization Asia, 1(1), 81-96. https://doi.org/10.1177/097542530900100107

Hamid, A., \& Masood, O. (2011). Selection criteria for Islamic home financing: a case study of Pakistan. Qualitative Research in Financial Markets, 3(2), 117-130. https://doi.org/10.1108/17554171111155357

Hasan, A. (2010). Migration, small towns and social transformations in Pakistan. Environment and Urbanization, 22(1), 33-50. 
https://doi.org/10.1177/0956247809356180

Hasan, A. (2015). Land contestation in Karachi and the impact on housing and urban development. Environment and Urbanization, 27(1), 217-230. https://doi.org/10.1177/0956247814567263

Institutions, C. W., \& Mohammed, M. O. (2016). Affordable Islamic Home Financing in Malaysia : a Potential Synergistic Venture Between Financial Cooperatives and CashWaqf, (October), 1-15.

Ismail, A. G., \& Shaikh, S. A. (2016). Using Waqf as Social Safety Net $\{\&\}$ Funding Public Infrastructure. Waqf IQLIMI 2015, USIM, 2015 (August 27, 2015), (AUGUST 2015), 029. https://doi.org/10.5897/JAERD12.088

Khan, M. K., Rasid, S. Z. A., Bardai, B. B. \& Fatima, B. (2019). Financial Cooperatives based on waqf for affordable housing in Karachi. International Journal of Academic Research in Business and Social Sciences, 9(8), 114-124.

Maali, B. M. \& Atmeh, M. A. (2015). Using social welfare concepts to guarantee Islamic banks' deposits. International Journal of Islamic and Middle Eastern Finance and Management, 8(2), 134-149. https://doi.org/10.1108/17538391111144515

Mohsin, M. I. A. (2013). Financing through cash-waqf: a revitalization to finance different needs. International Journal of Islamic and Middle Eastern Finance and Management, 6(4), 304-321. https://doi.org/10.1108/17538391111144515

Cizakca, M. (2013). The New Waqf Law Prepared By IDB/ IRTI and The Kuwait Public Foundation: A Critical Assessment , 2013, Kuala Lumpur. Islamic Wealth Management Inaugural Colloquium, 1-19.

Nafar, N. (2018). Affordable Housing Development and SDGs The Role of Islamic Finance, (January), 1-22.

Planning, R. (1992). Affordable Housing in Pakistan ', 15(4).

Qureshi, S., Breuste, J. H., \& Lindley, S. J. (2010). Green space functionality along an Urban gradient in Karachi, Pakistan: A socio-ecological study. Human Ecology, 38(2), 283-294. https://doi.org/10.1007/s10745-010-9303-9

RAVALLION, M., CHEN, S., \& SANGRAULA, P. (2007). (Literature) - New Evidence on the Urbanization of Global Poverty. Population and Development Review, 33(4), 35. https://doi.org/10.1111/j.1728-4457.2007.00193.x

Shafii, Z., \& Rahman, A. R. (2016). Issues on the application of IFRS9 and fair value measurement for Islamic financial instruments. Journal of Islamic Accounting and Business Research, 7(3), 202-214. https://doi.org/10.1108/JIABR-03-2016-0031

Shuid, S. (2011). Role of the State and Market in Low Cost Housing Provision: the Case Study of Open Registration System (Ors) for Low Cost House Buyers in Malaysia.

Smolo, E., \& Hassan, M. K. (2011). The potentials of Musharakah Mutanaqisah for Islamic housing finance. International Journal of Islamic and Middle Eastern Finance and Management, 4(3), 237-258. https://doi.org/10.1108/17538391111144515

Suzuki, Y., \& Miah, M. D. (2016). Altruism, reciprocity and Islamic equity finance. International Journal of Islamic and Middle Eastern Finance and Management, 9(2), 205-221. https://doi.org/10.1108/IMEFM-09-2014-0091

Zabri, M. Z., Mohammed, M. O., \& Mohammed, M. O. (2018). Qualitative validation of a financially affordable Islamic home financing model Qualitative validation of a $\mathrm{fi}$ nancially a ff ordable Islamic home fi nancing model. https://doi.org/10.1108/IJIF-082017-0023. 